УДК 7.071.2:378.147

DOI https://doi.org/10.24919/2308-4863/34-3-2

Ірина МАТІЙЧИН,

orcid.org/0000-0003-2153-8689

кандидат мистеитвознавства, доцент,

доиент кафедри методики музичного виховання і диригування Дрогобиџького державного педагогічного університету імені Івана Франка (Дрогобич, Львівська область, Україна) irynam65@ukr.net

Людмила ГРИГОРІВ, orcid.org/0000-0002-5733-092X

магістрант кафедри методики музичного виховання і диригування Дрогобиџького державного педагогічного університету імені Івана Франка (Дрогобич, Львівська область, Україна) ludka11097@ukr.net

\title{
ПРОБЛЕМИ ДИРИГЕНТСЬКОЇ ОСВІТИ КРІЗЬ ПРИЗМУ НАУКОВИХ ДОСЛІДЖЕНЬ У СУЧАСНІЙ УКРАЇНІ
}

\begin{abstract}
Пропонована стаття є джерелознавчою розвідкою, спрямованою на висвітлення актуальних проблем диригентської освіти украӥнськими науковцями кіния XX-початку XXI cm. Критично очінюючи навчально-методичну та наукову спадщииу вчених радянського періоду, українські музикознавиі та педагоги на новому етапі історичного розвитку зіткнулися з потребою переосмислення завдань диригентської освіти, ї̈ пріоритетів, проблем та перспектив. Мета нашої статті - показати, як у працях сучасних украйнських науковців відображено актуальні проблеми диригентської освіти.

У результаті проведеного дослідження виявлено, щчо у працях українських науковців кіния XX - початку XXI cm. відображається певний комплекс проблем, з якими стикаються викладачі та їхні підопічні в процесі роботи в класі хорового диригування. Йдеться, передусім, про навчально-методичне забезпечення навчальної дисиипліни «Хорове диригування», стан якого у всеукраӥнському вимірі свідчить, з одної сторони, про можливість вільного вибору підручників, навчальних посібників та хрестоматій хорових творів у повсякденній роботі. 3 іншої сторони, є проблема застарілості фонду навчальної літератури, більшу частину якого становлять російськомовні видання. Сучасна навчально-методична література видається в Україні нецентралізовано, скупими тиражами $і$ залишається маловідомою та маловживаною в загальноукраӥнському масштабі.

Низка статей присвячена проблемі формування фахових навичок студентів у класі хорового диригування на різних етапах навчання, деякі з них висвітлюють можливості застосування інновачійних технологій. Важливими для практичного застосування особистісного підходу на заняттях у класі диригування є праці психологічного спрямування. Водночас треба зазначити, щзо новаторських за змістом праць, присвячених теоріїхорового диригування, доволі мало. Малодослідженими залишаються проблеми розвитку спеціальних диригентських здібностей, проблеми суб 'єктної взаємодії на рівні студент/викладач, студент/концертмейстер (як прообраз майбутнього виконавського колективу), проблеми розширення арсеналу диригентських прийомів у сучасному виконавстві, проблеми дистаниійної освіти тощо, тому в иих ділянках є перспектива подальших наукових досліджень.
\end{abstract}

Ключові слова: диригентська освіта, актуальні проблеми, праці українських науковців. 


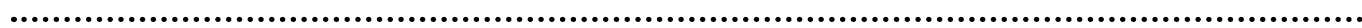

\author{
Iryna MATIYCHYN, \\ orcid.org/0000-0003-2153-8689 \\ Candidate of Art History, Associate Professor, \\ Associate Professor at the Department of Technique \\ of Musical Education and Conducting \\ Drohobych Ivan Franko State Pedagogical University \\ (Drohobych, Lviv region, Ukraine) irynam65@ukr.net
}

\author{
Liudmyla HRYHORIV, \\ orcid.org/0000-0002-5733-092X \\ Candidate for a Master's Degree at the Department of Technique \\ of Musical Education and Conducting \\ Drohobych Ivan Franko State Pedagogical University \\ (Drohobych, Lviv region, Ukraine)ludka11097@ukr.net
}

\section{PROBLEMS OF CONDUCTING EDUCATION THROUGH THE PRISM OF SCIENTIFIC RESEARCH IN MODERN UKRAINE}

The proposed paper is a source study aimed at covering topical issues of Ukrainian conducting education of the late 20th and early 21st century. Taking stock of educational, methodological and scientific heritage of scholars of the Soviet period, at a new stage of historical development Ukrainian musicologists and teachers face the challenge of having to rethink the tasks of conducting education, its priorities, problems and prospects. The objective of this paper is to highlight how topical issues of conducting education are reflected in the works of modern Ukrainian scholars.

The study found that the works of Ukrainian scholars of the late 20th and early 21st century reflected a certain array of problems that teachers and students faced in the process of working during the choral conducting classes. It is primarily about the educational and methodological support of the academic discipline "Choral Conducting". The methodological support situation in the all-Ukrainian dimension shows, on the one hand, that it is possible to freely choose textbooks, manuals and compilations of choral works in everyday work. But, on the other hand, the educational literature is outdated and the biggest part of it is Russian-language publications. Unfortunately, modern educational and methodical literature is being published in Ukraine on a noncentralized basis, in the small print runs and thus remains little known and little used on an all-Ukrainian scale.

A number of research papers are devoted to the problem of forming professional skills of choral conducting students at different stages of education. Some of them highlight the possibilities of using innovative technologies. The works of psychological nature are also important for the practical application of a personal approach in teaching the conducting. However, it should be noted that the choice of innovative works on the theory of choral conducting is limited. There has been little research into problems of development of special conducting skills, problems of subjective student/teacher, student/concertmaster interaction (as a prototype of the future performing team), problems of expanding the range of conducting techniques in modern performance, problems of distance education, etc. Many issues remain unresolved in these areas and require further research.

Key words: conducting education, topical issues, works of Ukrainian scholars.

Постановка проблеми. Музикознавство незалежної України молоде, як і сама держава, хоча і має певні традиції розвитку, закладені в попередні часи українськими вченими Б. Кудриком, П. Козицьким, М. Антоновичем К. Майбуровою, Я. Ісаєвичем та ін. Власне система фахової диригентської освіти в Україні сформувалася у II половині XX ст., а почала осмислюватися як явище ще пізніше. Навчально-методичні посібники М. Колесси, К. Пігрова, І. Розумного, А. Болгарського, М. Канерштейна та ін. заклали основи системної диригентсько-хорової освіти в Україні, а наукові праці українських вчених XX ст. стали передумовою вивчення розвитку сучасного українського музикознавства, дотичного до проблем диригентської освіти. Адже в наш час мистецька освіта загалом, а диригентська зокрема, розвива- ється, модернізується, старається відповідати на нові виклики, які постають перед нею. Із постанням незалежності України виникла потреба оцінити і переосмислити завдання диригентської освіти, їі пріоритети, проблеми та перспективи.

Аналіз досліджень. Окреслення низки найбільш важливих проблем диригентської освіти знаходимо у працях А. Мартинюка, Л. Ярошевської, Р. Любар, І. Куфлюк, А. Растригіної, М. Камінської, М. Ляшка та ін. Так, у дисертаційному дослідженні А. Мартинюка «Диригентськохорова освіта в музичній культурі України другої половини XX століття» перелічено такі іiі проблеми, як «розкриття специфічних рис диригентського мистецтва і його взаємозв'язку з функціонуванням художнього колективу як соціального організму, простеження еволюції диригентського 
мистецтва та виникнення його сучасних форм, аналіз диригентської діяльності як складного багатофункціонального психіко-фізіологічного процесу, обгрунтування структури диригентської обдарованості, виявлення передумов формування художньої індивідуальності диригента, розкриття внутрішніх закономірностей диригентської техніки» (Мартинюк, 2001: 5). Загалом погоджуючись iз переліком згаданих проблем (точніше, комплексів проблем), треба наголосити, що в педагогічній діяльності їх постає значно більше, але далеко не всі вони поки що знайшли відображення у працях українських науковців.

Мета статті - показати, як у працях українських науковців кін. XX - поч. XXI ст. відображено актуальні проблеми диригентської освіти.

Виклад основного матеріалу. Сучасна диригентська освіта в Україні сформувалася інституційно в радянський період, відповідно, успадкувала як переваги, так і недоліки радянської системи музичної освіти. Систематична робота в класі хорового диригування, попри спрямування на виконання навчальних програм, мусить спиратися на фахову навчально-методичну літературу. Тому чи не першочерговою в забезпеченні якісної диригентської освіти постає проблема навчальнометодичного забезпечення, адже, переглянувши фонди навчальних бібліотек, бачимо, що більша частина була видана ще у радянські часи, причому переважно російською мовою. Про нові тенденції в галузі диригентсько-хорового мистецтва, проблеми виконання сучасних хорових творів тощо можемо дізнатися тільки 3 новіших праць педагогів, музикознавців та диригентів-практиків.

За роки незалежності України вийшло кілька підручників із методики диригування, а саме: «Диригування: навчальний посібник» (Мартинюк, 1996), «Методика викладання диригування» (Доронюк, 2005), «Основи хорового диригування» (Прокулевич, 2016), «Методика викладання хорового диригування» (Костенко, Шумська, 2019). Крім того був виданий посібник «Диригент шкільного хору» (Доронюк, Серганюк, Серганюк, 2009), спрямований на виховання диригента шкільного хорового колективу. Видані обмеженим тиражем, та ще й у периферійних видавництвах, ці підручники залишаються маловідомими в загальноукраїнському масштабі, хоча зацікавлені особи можуть iз ними познайомитися через Інтернет. Малодоступними для використання в навчальній роботі $\epsilon$ і монографії П. Шеметова «Школа концертнодиригентського мистецтва» (Шеметов, 2004) i Т. Смирнової «Теорія та методика диригентськохорової освіти у вищих навчальних закладах: пси- холого-педагогічний аспект» (Смирнова, 2008), а також цікава $з$ точки зору психології брошура відомого диригента Р. Кофмана «Виховання диригента. Психологічні особливості» (Кофман, 1986), видана в часи перебудови.

Проблема репертуарного оновлення навчальних програм хорового диригування вирішується виданням на місцях нотованих хрестоматій (наприклад, «Хрестоматія 3 хорового диригування» (Заруба, Растригіна, 2004)), доступність яких залежить від тиражу (а отже, від фінансування), адже через Інтернет ними скористатися не можна. А загалом проблема навчальнометодичного забезпечення диригентської освіти висвітлена (хоч і не вичерпно) у статті А. Соколової «Навчально-методичне забезпечення диригентсько-хорової підготовки вчителів музичного мистецтва» (Соколова, 2015), в якій розглядається як базова методична література радянського періоду, залишаючи дослідження педагогічного доробку з диригентських дисциплін періоду незалежної України своїм послідовникам.

Дещо інший підхід до використання методичного доробку видатних педагогів і диригентів у навчальній роботі висловлює Т. Смирнова у статті «Педагогічні ідеї представників української диригентсько-хорової педагогіки ХХ століття». Дослідниця висвітлює процес еволюції науково-педагогічної думки у сфері української диригентської освіти радянської доби, кристалізуючи передові ідеї ¥і1 найяскравіших представників. «У радянський період розвитку вітчизняної вищої диригентсько-хорової освіти затвердилися педагогічні ідеї щодо запровадження національних пріоритетів і демократизації освіти, важливості поглибленої професіоналізації змісту, методів, форм підготовки диригентів хору, виховання студентів як яскравих творчих індивідуальностей. <..> Для другого періоду - становлення незалежної диригентсько-хорової педагогіки (кінець ХХ століття)характерною є реалізація принципу диференціації та індивідуалізації навчання диригентів хору в закладах різного профілю (мистецтва, культури, педагогічних університетах); підвищення ролі феноменологічного та етнокультурного підходів, що вимагало індивідуалізації диригентсько-хорової освіти, поглиблення змісту освіти цінностями національної культури» (Смирнова, 2016: 62).

Близька за змістом до праці Т. Смирнової стаття Н. Гречаника «Вплив педагогічних ідей та досвіду видатних диригентів-хормейстерів на методичну підготовку майбутнього вчителя музики» включає осмислення досвіду, крім українських, ще й російських диригентів та педагогів. Н. Гречаник 
висвітлює висловлені ними основні недоліки в системі диригентської освіти, які потребують вирішення, а саме: «недостатня увага диригентсько-хоровій практиці; відсутність інтегруючих процесів музичних дисциплін в класах хорового практикуму; відсутність спрямованості діяльності педагогів на розвиток і формування творчої самостійності особистості майбутнього музикантапедагога; домінування технократичного підходу до викладання дисциплін диригентсько-хорового циклу, «натаскування» вокальної, диригентської техніки; часткове ігнорування індивідуальних особливостей суб“єкту навчання; недостатня увага педагогів до проблеми психолого-педагогічних умов музичного навчання з більшості диригентсько-хорових дисциплін» (Гречаник, 2012: 53).

Важливими для подолання проблем технічного освоєння основ диригентської майстерності $€$ низка статей українських науковців відповідної тематики. Так, у статті Т. Голованя «Формування навичок основ техніки диригування у студентівпочатківців» сконцентровано головні положення, на яких має грунтуватися початкова робота в класі хорового диригування. Розкриваючи послідовність роботи 3 початківцями, автор статті слушно зазначає: «3 перших занять слід вимагати від студента максимальної природності положення рук, простоти, ясності, наочності жесту, які роблять зручною роботу диригента і сприяють якнайкращому розумінню його намірів хором» (Головань, 2010: 130). Для закріплення базових навичок диригування корисною буде стаття А. Дудаш «Вдосконалення диригентської майстерності студентів ВНЗ ОС «Бакалавр», в якій авторка пропонує введення в практику навчальної роботи в класі хорового диригування методів порівняльного втілення художніх образів, а також застосування для самоконтролю студентів розробленої нею пам'ятки, яка відображає основні аспекти аналізу виконання конкретних навчальних завдань 3 диригування (Дудаш, 2018: 114-115). А більш досвідченим студентам та їх викладачам стане в пригоді ст. 3. Яропуда «Методика застосування основних схем i ïx варіантів у диригуванні творів немензурованого безрозмірного письма», в якій автор на конкретних прикладах демонструє принципи вибору відповідних для кожного випадку схем диригування, спираючись на такі фактори, як логіка словесного тексту, фразування, групування, темп, а особливо на метро-ритмічну структуру твору і внутрішній склад кожного розміру зокрема. При цьому 3. Яропуд наголошує: «Робота 3 духовними творами безрозмірного письма у класі диригування має передусім враховувати відповідальне став- лення до богослужбового слова. Саме аналіз тексту, його ясне розуміння $є$ головними критеріями для диригента у виборі тактових схем, адекватних виконавській інтерпретації духовного піснеспіву, а єдність слів і музики робить духовну музику провідним освітньо-виховним засобом» (Яропуд, 2017: 354-355).

Методично вартісною постає стаття Л. Теряєвої «Етапи формування методичної компетентності майбутніх учителів музики на заняттях 3 хорового диригування», в якій авторка дотримується принципів системності та послідовності у викладі навчального матеріалу. Визначаючи етапи формування методичної компетентності студентів (мотиваційно-пізнавальний, самостійно-пошуковий, діяльнісно-творчий), Л. Теряєва провела детальний аналіз кожного 3 них та висвітлила значення їхньої комплексної взаємодії (Теряєва, 2017: 263). Особливу увагу у статті приділено важливості використання у процесі навчання інноваційних технологій, зокрема музичних комп'ютерних програм.

Висвітленню проблем формування вербальних та невербальних навичок спілкування майбутніх диригентів із хоровим колективом присвятила відповідні праці О. Лєснік. Так, у статті «Діалогічне спілкування як засіб формування художньо-мовленнєвих умінь майбутніх учителів музичного мистецтва в процесі хормейстерської підготовки» авторка слушно наголошує: «Специфіка діалогічного спілкування (інформативна підготовленість, якість мовних висловлювань), вербальна форма мовлення допомагають закласти основи адекватності невербальної мови диригента - диригентського жесту, його інформативності, відповідності художнім характеристикам вокально-хорового твору» (Лєснік, 2019, 221). А у статті «Формування невербального компонента художньо-мовленнєвих умінь майбутніх учителів музики» О. Лєснік, відштовхуючись від вербального досвіду спілкування, пропонує низку методів, які сприятимуть ефективному формуванню невербального компоненту, а саме:

- побудування асоціативного ряду (вербального, графічного, моторного), що передбачає підбір слів, які позначають предмети і явища, що володіють визначеними якісними характеристиками;

- переведення внутрішніх уявлень на мову образів, що сприймаються за допомогою зору, підбір рухових еквівалентів, що відповідають тій чи іншій забарвленості чи якісній характеристиці;

- звернення до особистого рухового досвіду із соціально-побутової поведінки, відтворення окремих елементів, ланцюга рухових елементів одного ряду, ланцюга доцільних комбінованих рухів; 
- створення пластичних «мініетюдів»;

- метод візуальних доповідей за допомогою міміки, пантоміміки та пластики (Лєснік, 2011: 58).

Деякі науковці у своїх дослідженнях звертають увагу на особистісний підхід у навчальновиховній роботі 3 майбутніми диригентами. Вочевидь, в умовах індивідуального навчання у класі диригування такий підхід $є$ єдино правильним, проте потребував теоретичного осмислення, тому й відобразився у працях українських педагогів та музикознавців. Зокрема, у статті I. Цюряк та С. Роговської «Особистісний підхід у диригентсько-хоровій підготовці студентів-магістрів» подається розроблена ними схема, в якій висвітлюються такі умови функціонування особистісного підходу в навчанні: організація діалогової взаємодії в навчально-виховному процесі; забезпечення психологічного комфорту для студента на заняттях; диференційований підхід до особистісних якостей майбутнього вчителя музики, їх корекції в умовах вишівського навчання; створення можливостей для художньо-творчої самореалізації, самовдосконалення й саморозвитку студентів (Цюряк, Роговська, 2018: 86-87). Додамо, що застосування особистісного підходу вимагає від викладача диригування гарних знань із педагогіки та психології, а також високої здатності до емпатії, вміння відчувати себе на місці свого студента 3 його характером, установками, соціальним досвідом. Важливим $є$ налагодження довіри між викладачем i студентом, тільки в умовах особистісної взаємодії процес навчання буде ефективним.

Особистісний (або індивідуальний) підхід $\epsilon$ тільки однією ланкою в системі осучаснення навчальної роботи в класі хорового диригування. У статті «Інноваційні принципи навчання у формуванні методичної компетентності майбутніх учителів музики на заняттях 3 хорового диригування» Л. Теряєва, підсумовуючи новаторські ідеї інших науковців, пропонує застосовувати в диригентському класі такі принципи: індивідуалізації, національної ідентичності, наукового пізнання, інтенсифікації навчання, інтерактивного навчання, інноваційної наочності, креативного розвитку, підвищення рівня IT, змагальності, міждисциплінарних зв'язків, оптимізації навчального процесу (Теряєва, 2016: 118). Попри безперечну вартість описаних авторкою підходів, застосовувати їх у повсякденній роботі видається можливим за браком часу тільки вибірково, зважаючи на сучасні умови організації навчання, за яких сітка індивідуальних годин завжди піддається т. зв. оптимізації, коригуванню в бік скорочення.
Дещо інші акценти знаходимо в статті I. Топчієвої «Орієнтири оновлення диригентсько-хорової підготовки студентів факультетів мистецтв педагогічних університетів», в якій авторка стверджує: «Інноваційне облаштування диригентсько-хорової підготовки зумовлює інтелектуальну насиченість навчального процесу, а саме: постановку педагогом проблемних і дискусійних питань, висвітлення різних підходів до трактування музичних творів, провокування студентів до коментарів, створення авторських моделей інтерпретацій художніх образів тощо» (Топчієва, 2019: 244). I хоча такий підхід потребує додаткових зусиль як викладача, так і студента, у плані професійного розвитку останнього він видається доволі перспективним.

Цікаві питання включеності розвитку диригента у світовий контекст розглядає стаття Л. Ластовецької «Вплив глобалізаційних процесів на формування творчої індивідуальності диригента». У ній йдеться про розширення можливостей для творчого зростання диригентів через участь у міжнародних конкурсах та фестивалях, майстер-класах диригентської майстерності, закордонних гастролях та культурних проектах як із виконавськими колективами, так і самостійно, готуючи концертні програми 3 різними складами виконавців. Л. Ластовецька звертає увагу, що «глобалізація, як система відкритого культурного обміну, дала змогу сучасним диригентампочатківцям навчатися майстерності не тільки в класі у педагога, але й на прикладах відомих професіоналів за допомогою 3МI, Інтернету, нерідко спостерігаючи за ними в режимі on-line на концертних виступах та під час їх репетицій» (Ластовецька, 2011: 115). Водночас у статті зазначаються і окремі перестороги, пов’язані з глобалізаційними процесами, зокрема «загроза «стирання» чи часткової втрати місцевих етнічних начал, локальних культурних осередків, давніх народнопісенних пластів, вивчення яких необхідне для сучасної культури» (Ластовецька, 2011: 115). Неочікуваною загрозою культурним обмінам стала спровокована глобалізацією теперішня пандемія коронавірусної інфекції, великою мірою законсервувавши можливості творчих поїздок диригентів та їх виконавських колективів та значно обмеживши концертну діяльність загалом. Більше того, значно звузилися можливості для повноцінної диригентсько-хорової освіти.

У цих умовах актуальною постає проблема дистанційного навчання, яка тільки починає осмислюватися в музичній педагогіці. У статті О. Калюжної «Роль дистаційного навчання у формуванні мистецьких компетентностей майбутніх педагогів- 
музикантів» відзначаються позитивні можливості навчання «на відстані», однак слушно наголошено, що ця форма освіти «може мати тимчасовий характер, особливо при вивченні спеціальних предметів (постановка голосу, хорове диригування та ін.)» (Калюжна, 2015: 148). Сучасна практика підтверджує висновок авторки, доводячи, що дистанційна освіта не може вважатися повноцінною формою навчальної діяльності у сфері практичної виконавської підготовки, у т. ч. хорового диригування. Однак елементи дистанційного навчання в освітній підготовці диригентів застосовувати доцільно і корисно. Як саме і в яких формах - це питання для нових досліджень та експериментів.

Висновки. У межах статті неможливо окреслити коло всіх проблем диригентської освіти, які розглядаються в наукових дослідженнях українських учених. Підсумовуючи, треба сказати, що у працях українських науковців кінця XX - початку XXI ст. відображається певний комплекс проблем, 3 якими стикаються викладачі та їх підопічні в процесі роботи в класі хорового диригування. Йдеться передусім про навчально-методичне забезпечення навчальної дисципліни «Хорове диригування», стан якого у всеукраїнському вимірі свідчить, 3 одної сторони, про можливість вільного вибору підручників, навчальних посібників та хрестома- тій хорових творів у повсякденній роботі. 3 іншої сторони, є проблема застарілості фонду навчальної літератури, більшу частину якого становили російськомовні видання. Сучасна навчальнометодична література видавалася в Україні нецентралізовано, скупими тиражами і залишається маловідомою та маловживаною в загальноукраїнському масштабі.

Низка статей присвячена проблемі формування фахових навичок студентів у класі хорового диригування на різних етапах навчання, деякі 3 них висвітлюють можливості застосування інноваційних технологій. Важливими для практичного застосування особистісного підходу на заняттях у класі диригування є праці психологічного спрямування. Водночас треба зазначити, що новаторських за змістом праць, присвячених теорії хорового диригування, доволі мало. Малодослідженими залишаються проблеми розвитку спеціальних диригентських здібностей, проблеми суб'єктної взаємодії на рівні студент/ викладач, студент/концертмейстер (як прообраз майбутнього виконавського колективу), проблеми розширення арсеналу диригентських прийомів у сучасному виконавстві, проблеми дистанційної освіти тощо, тому в цих ділянках $\epsilon$ перспектива подальших наукових досліджень.

\section{СПИСОК ВИКОРИСТАНИХ ДЖЕРЕЛ}

1. Головань Т. Формування навичок основ техніки диригування у студентів-початківців. Наукові записки НДУ ім. М. Гоголя. Психолого-педагогічні науки. 2012. № 1. С. 129-132.

2. Гречаник Н. Вплив педагогічних ідей та досвіду видатних диригентів-хормейстерів на методичну підготовку майбутнього вчителя музики. Науковий часопис НПУ ім. М. П. Драгоманова. Серія 16: Творча особистість учителя: проблеми теорії і практики. 2010. Вип. 13. С. 50-54.

3. Доронюк В. Методика викладання диригування. Івано-Франківськ, 2005. 128 с.

4. Доронюк В., Серганюк Л., Серганюк Ю. Диригент шкільного хору. Івано-Франківськ, 2009. 490 с.

5. Дудаш А. Вдосконалення диригентської майстерності студентів ВНЗ ОС «Бакалавр». Освіта i наука. 2018. Вип. 2 (25). С. 112-116.

6. Заруба Е. С., Растригіна А. М. Хрестоматія з хорового диригування: навчально-методичний посібник для музичних відділень мистецьких факультетів. Кіровоград: РВВ КДПУ ім. В. Винниченка, 2004. 104 с.

7. Калюжна О. Роль дистаційного навчання у формуванні мистецьких компетентностей майбутніх педагогівмузикантів. Наукові записки КДПУ ім. В. Винниченка. Педагогічні науки. 2015. Вип. 139. С. 147-149.

8. Костенко Л., Шумська Л. Методика викладання хорового диригування : навч. посіб. для магістрантів закладів вищої освіти. 2-ге вид., доповнене та перероблене. Ніжин : НДУ ім. М. Гоголя, 2019. 145 с.

9. Кофман Р. І. Виховання диригента. Психологічні особливості. Київ : Музична Україна, 1986. 40 с.

10. Ластовецька Л. Вплив глобалізаційних процесів на формування творчої індивідуальності диригента. Молодь і ринок. 2011. № 10 (81). С. 114-116.

11. Лєснік О. Діалогічне спілкування як засіб формування художньо-мовленнєвих умінь майбутніх учителів музичного мистецтва в процесі хормейстерської підготовки. Наукові записки Центральноукраїнського державного педагогічного університету імені Володимира Винниченка. Педагогічні науки. Кропивницький : ЦДПУ ім. Володимира Винниченка, 2019. Вип. 176. С. 217-222.

12. Лєснік О. Формування невербального компоненту художньо-мовленнєвих умінь майбутніх учителів музики. Науковий вісник Південноукраӥнського національного педагогічного університету ім. К. Д. Ушинського. 2011. № 11-12. С. 53-59.

13. Мартинюк А. Диригентсько-хорова освіта в музичній культурі України другої половини ХХ століття : автореф. дис. ... канд. мист. : 17.00.01 / Харківська державна академія культури. Харків, 2001. 20 с.

14. Мартинюк А. К. Диригування : навч. посібник. Мелітополь, 1996. 125 с.

15. Прокулевич О. Основи хорового диригування. Умань, 2016. 140 с. 
16. Смирнова Т. Педагогічні ідеї представників української диригентсько-хорової педагогіки ХХ століття. Актуальні питання мистецької освіти та виховання. 2016. Вип. 1 (7). С. 58-62.

17. Смирнова Т. А. Теоретичні і методичні засади диригентсько-хорової освіти у вищих навчальних закладах : автореф. дис. ... д-ра пед. наук : 13.00.04 / Ін-т пед. і психол. проф. освіти АПН України. Київ, 2004. 40 с.

18. Смирнова Т. Теорія та методика диригентсько-хорової освіти у вищих навчальних закладах: психолого-педагогічний аспект : монографія. Харків. нац. пед. ун-т ім. Г. С. Сковороди. Горлівка: Ліхтар, 2008. 445 с.

19. Соколова А. Навчально-методичне забезпечення диригентсько-хорової підготовки вчителів музичного мистецтва. Проблеми підготовки сучасного вчителя. 2015. № 12. С. 84-94.

20. Теряєва Л.А. Етапи формування методичної компетентності майбутніх учителів музики на заняттях із хорового диригування. Наукові записки КДПУ ім. В. Винниченка. Педагогічні науки. Кропивницький : РВВ КДПУ ім. В. Винниченка, 2017. Вип. 150. С. 262-264.

21. Теряєва Л. Інноваційні принципи навчання у формуванні методичної компетентності майбутніх учителів музики на заняттях з хорового диригування. Науковий збірник «Музичне мистецтво в освітологічному дискурсі». 2016. № 1. C. 117-122.

22. Топчієва І. Орієнтири оновлення диригентсько-хорової підготовки студентів факультетів мистецтв педагогічних університетів. Науковий вісник МНУ імені В. О. Сухомлинського. Педагогічні науки. 2019. № 1 (64). С. $243-246$.

23. Цюряк І. Роговська Є. Особистісний підхід у диригентсько-хоровій підготовці студентів-магістрів. Імідж сучасного педагога. 2018. № 6 (183). С. 84-88.

24. Шеметов П. Школа концертно-дирижерского искусства. Харьков : Левий берег, 2004. 302 с.

25. Яропуд 3. Методика застосування основних схем і їх варіантів у диригуванні творів немензурованого безрозмірного письма. Хорове мистецтво Украӥни та його подвижники: матеріали VI міжнародної, науково-практичної інтернет-конференції. Дрогобич, 2017. С. 345-355.

\section{REFERENCES}

1. Holovan T. Formuvannya navychok osnov tekhniky dyryhuvannya u studentiv-pochatkivtsiv [Formation of skills of basic conducting technique in beginner students]. Research notes of Nizhyn Mykola Gogol State University. Psycholgy and Pedagogy Research, 2012, № 1, pp. 129-132 [in Ukrainian].

2. Hrechanyk N. Vplyv pedahohichnykh idey ta dosvidu vydatnykh dyryhentiv-khormeysteriv na metodychnu pidhotovku maybutnyoho vchytelya muzyky [Influence of pedagogical ideas and experience of prominent conductors-choirmasters on methodical training of a future music teacher]. Scientific journal of National Pedagogical Dragomanov University. Series 16: Tvorcha osobystist' uchytelya: problemy teoriyi i praktyky, 2010, Issue 13, pp. 50-54 [in Ukrainian].

3. Doronyuk V. Metodyka vykladannya dyryhuvannya. [Conducting teaching techniques]. Ivano-Frankivsk, $2005,128 \mathrm{p}$. [in Ukrainian].

4. Doronyuk V., Serhanyuk L., Serhanyuk Yu. Dyryhent shkilnoho khoru. [Conductor of the school choir]. IvanoFrankivsk, 2009, 490 p. [in Ukrainian].

5. Dudash A. Vdoskonalennya dyryhentskoyi maysternosti studentiv [Improving the conducting skills of university students] VNZ OS «Bakalavr». Osvita i nauka, 2018, Issue 2 (25), pp. 112-116 [in Ukrainian].

6. Zaruba E., Rastryhina A. Khrestomatiya $\mathrm{z}$ khorovoho dyryhuvannya: navchalno-metodychnyy posibnyk dlya muzychnykh viddilen' mystetskykh fakultetiv. [Chrestomathy on choral conducting: a textbook for music departments of art faculties]. Kirovohrad: RVV of V. Vynnychenko KSPU, 2004, p. 104 [in Ukrainian].

7. Kalyuzhna O. Rol dystatsiynoho navchannya u formuvanni mystetskykh kompetentnostey maybutnikh pedahohiv-muzykantiv. [The role of distance education in the formation of artistic competencies of future teachers-musicians]. Researchnotes of Volodymyr Vynnychenko State Pedagogical University. Kirovohrad, 2015, Iss. 139,pp. 147-149 [in Ukrainian].

8. Kostenko L., Shumska L. Metodyka vykladannya khorovoho dyryhuvannya: navch. posib. dlya mahistrantiv zakladiv vyshchoyi osvity. 2-he vyd., dopovnene ta pereroblene [Methods of choral conducting teaching: a textbook for undergraduates of higher education institutions]. 2nd ed., supplemented and revised. Nizhyn: [Nizhyn Mykola Gogol State University], 2019, p. 145 [in Ukrainian].

9. Kofman R. Vykhovannya dyryhenta. Psykholohichni osoblyvosti. [Education of a conductor. Psychological features]. Kyiv: Muzychna Ukrayina, 1986, p. 40 [in Ukrainian].

10. Lastovetska L. Vplyv hlobalizatsiynykh protsesiv na formuvannya tvorchoyi indyvidualnosti dyryhenta. [The influence of globalization processes on the formation of a creative personality of a conductor]. Youth \& Market, 2011, № 10 (81), pp. 114-116 [in Ukrainian].

11. Lyesnik O. Dialohichne spilkuvannya yak zasib formuvannya khudozhnyo-movlennyevykh umin' maybutnikh uchyteliv muzychnoho mystetstva $\mathrm{v}$ protsesi khormeysterskoyi pidhotovky. [Dialogic communication as a means of forming artistic and speech skills of future music teachers in the process of choirmaster training]. Research notes of Volodymyr Vynnychenko Central Ukrainian State Pedagogical University. Pedagogical sciences. Kropyvnytskyi: 2019, Issue. 176, pp. 217-222 [in Ukrainian].

12. Lyesnik O. Formuvannya neverbalnoho komponentu khudozhno-movlennyevykh umin' maybutnikh uchyteliv muzyky. [Formation of a non-verbal component of artistic and speech skills of future music teachers]. Scientific bulletin of South Ukrainian National Pedagogical University named after K. D. Ushynsky, 2011, № 11-12, pp. $53-59$ [in Ukrainian].

13. Martynyuk A. Dyryhentsko-khorova osvita v muzychniy kulturi Ukrayiny druhoyi polovyny XX stolittya [Choral conducting education in musical culture of Ukraine in the 2nd half of the 20th century]: abstract of dissertation (Candidate of Art Criticism): 17.00.01 / Kharkiv State Academy of Culture. Kharkiv, 2001, p. 20 [in Ukrainian]. 
14. Martynyuk A. Dyryhuvannya: navch. posibnyk. [Conducting: textbook]. Melitopol, 1996, p. 125 [in Ukrainian].

15. Prokulevych O. Osnovy khorovoho dyryhuvannya. [Fundamentals of choral conducting]. Uman, 2016, p. 140 [in Ukrainian].

16. Smyrnova T. Pedahohichni ideyi predstavnykiv ukrayinskoyi dyryhentsko-khorovoyi pedahohiky XX stolittya. [Pedagogical ideas of representatives of Ukrainian choral conducting pedagogy of the 20th century]. Aktualni pytannya mystetskoyi osvity ta vykhovannya. "Topical Questions of Artistic Pedagogics" 2016, Iss. 1 (7), pp. 58 -62 [in Ukrainian].

17. Smyrnova T. A. Teoretychni i metodychni zasady dyryhentsko-khorovoyi osvity u vyshchykh navchalnykh zakladakh: [Theoretical and methodical principles of choral conducting education in higher educational institutions]: abstract of dissertation (Doctor of Pedagogic Sciences): 13.00.04 / Institute of Pedagogical and Adult Education of NAES of Ukraine. Kyiv, 2004, p. 40 [in Ukrainian].

18. Smyrnova T. Teoriya ta metodyka dyryhents'ko-khorovoyi osvity u vyshchykh navchalnykh zakladakh: psykholoho-pedahohichnyy aspekt: [Theory and methods of choral conducting education in higher education institutions: psychological and pedagogical aspect]: monograph. Kharkiv. H. S. Skovoroda Kharkiv National Pedagogical University. Horlivka: Likhtar, 2008, p. 445 [in Ukrainian].

19. Sokolova A. Navchalno-metodychne zabezpechennya dyryhentsko-khorovoyi pidhotovky vchyteliv muzychnoho mystetstva. [Educational and methodical support of choral conducting training of music teachers]. Problemy pidhotovky suchasnoho vchytelya. Problems of modern teacher training, 2015, № 12, pp. 84-94 [in Ukrainian].

20. Teryayeva L.A. Etapy formuvannya metodychnoyi kompetentnosti maybutnikh uchyteliv muzyky na zanyattyakh $\mathrm{z}$ khorovoho dyryhuvannya. [Stages of formation of method competence of future music teachers during choral conducting classes]. Research notes of Volodymyr Vynnychenko Central Ukrainian State Pedagogical University. Pedagogical sciences. Kropyvnytskyi: RVV of V. Vynnychenko KSPU, 2017, Iss. 150, pp. 262-264 [in Ukrainian].

21. Teryayeva L. Innovatsiyni pryntsypy navchannya u formuvanni metodychnoyi kompetentnosti maybutnikh uchyteliv muzyky na zanyattyakh $\mathrm{z}$ khorovoho dyryhuvannya. [Innovative training principles in the formation of method competence of future music teachers during choral conducting classes]. Naukovyy zbirnyk "Muzychne mystetstvo v osvitolohichnomu dyskursi". Scientific journal "Musical art in the educological discourse”. Kyiv: B. Grinchenko Kyiv University, 2016 , № 1. Pp. 117-122 [in Ukrainian].

22. Topchiyeva I. Oriyentyry onovlennya dyryhentsko-khorovoyi pidhotovky studentiv fakultetiv mystetstv pedahohichnykh universytetiv. [Landmarks of updating choral conducting training of art students of pedagogical universities]. Scientific Bulletin of V. O. Sukhomlynskyi Mykolaiv National University. Pedagogical Sciences, 2019, № 1 (64), pp. 243-246 [in Ukrainian].

23. Tsyuryak I. Rohovska Ye. Osobystisnyy pidkhid u dyryhentsko-khoroviy pidhotovtsi studentiv-mahistriv. [Personal approach in choral conducting training of master’s students]. Image og the modern pedagogue, 2018, № 6 (183), pp. 84-88 [in Ukrainian].

24. Shemetov P. Shkola kontsertno-dyryzherskoho iskusstva. [School of concert conducting art]. Kharkiv: Livyi bereh, 2004, p. 302 [in Russian].

25. Yaropud Z. Metodyka zastosuvannya osnovnykh skhem i yikh variantiv u dyryhuvanni tvoriv nemenzurovanoho bezrozmirnoho pysma. [Methods of application of basic patterns and their variants in conducting music works in unmensurated unmeasured notation]. Khorove mystetstvo Ukrayiny ta yoho podvyzhnyky: materialy VI mizhnarodnoyi, naukovo-praktychnoyi internet-konferentsiyi Choral art of Ukraine and its devotees: materials of the 6th international, scientific and practical Internet conference. Drohobych, 2017, pp. 345-355 [in Ukrainian]. 